\section{Use of slow sand filtration technique to improve wastewater effluent for crop irrigation}

\author{
Chebor Joel, Lizzy A. Mwamburi, \\ Ezekiel K. Kiprop \\ Department of Biological Sciences, \\ University of Eldoret, Kenya
}

\begin{abstract}
Water scarcity has resulted to urban residence to resort to using untreated wastewater to irrigate their crops. This practice raises concerns on health of the farmers and consumers of the crops. The study aimed at determining whether the effluent from Boundary Sewage Treatment Plant was up to national and international standards recommended for irrigation, if not they were further subjected to slow sand filtration of different sand sizes $(0.1$ and $0.05 \mathrm{~mm})$ to polish the effluent. Pour plate method was used to determine total coliforms (TC), Biological oxygen demand (BOD) technique for BOD, chemical oxygen demand (COD) digestion for COD, gravimetric method for total dissolved solids (TDS) and total suspended solids (TSS). One sample t-test during dry season showed that BOD, COD, TC and TSS in the effluent were significantly higher $(\mathrm{P}<0.05)$ than the standards for irrigation. During wet season BOD, COD, TDS and $\mathrm{pH}$ were significantly not higher $(\mathrm{P}>0.05)$ than the compared standards for the wastewater to be used for crop irrigation. The filters improved the effluent from the treatment plant to the standards for irrigation. The sequential treatment of the raw wastewater by the Boundary Sewage Treatment Plant and the slow sand filtration technique made the wastewater to achieve the standards it can be utilized for crop irrigation.
\end{abstract}

\section{Introduction}

In many countries water is becoming an increasingly scarce resource. Due to increasing population and industries as well as urban expansion, the production of wastewater and its reuse has grown rapidly. The reuse of treated wastewater for irrigation is a practical solution to overcome water scarcity, especially in arid and semiarid regions. ${ }^{1}$ Wastewater has long been used as a resource in agricultural production. It has recently been approximated that about 20 million hectares of land are irrigated with treated, partially treated, diluted and untreated wastewater in developing coun- tries. ${ }^{2,3}$ According to the World Health Organization (WHO), $10 \%$ of the world's population relies on food grown with contaminated wastewater. ${ }^{4}$

Wastewater has many advantages including supplying both organic matter and mineral nutrients to soil that are beneficial to crop production, and reduce the cost of fertilizer for crop application. ${ }^{5}$

Conventional wastewater treatment methods that are aimed at reducing the pollutant load on the environment in most cases release effluents that are still high in Biological Oxygen Demand (BOD), nitrogen and phosphorous nutrients and bacterial load thus posing danger to the receiving environment. ${ }^{6,7}$ Health problems and diseases are often caused by discharging untreated or inadequately treated effluent into the soil for agriculture. Slow sand filtration is a simple technology that can be used to reduce the pollutant load of wastewater to the standards for irrigation. 8,9 However, little work has been done on the application of Slow Sand Filters (SSFs) in wastewater quality improvement. ${ }^{10}$ The process is passive and the effectiveness of the filters is dependent upon the development of a biofilm attached to sand grains. ${ }^{11}$

With increased volumes of untreated or partially treated wastewater being used for crop irrigation, there is need to develop reliable methods to mitigate the health risks that can be caused by microorganisms in water and other physicochemical substances. The objectives of this study were to quantify the amount of the microbiological and physiochemical parameters in the effluent obtained from Boundary Sewage Treatment Plant and compare it with national and international standards for treated wastewater to be used for crop irrigation. If the effluent was not up to the standards then the effluent was subjected to slow sand filtration for further purification.

\section{Materials and Methods}

\section{Study area}

The study was carried out at Boundary Sewage Treatment Plant in Eldoret, Uasin Gishu County, Kenya. The plant is located at latitude of $0.52^{0} \mathrm{~N}$ and $35.28^{0} \mathrm{E}$. It is one of the conventional wastewater treatment plants within Eldoret town, it treats both industrial and domestic wastewater. Furthermore the plant also receives domestic wastewater from the latrines and septic tanks from various households within the town which are transported by honey sucker truck to this treatment plant for disposal. The plant relies almost entirely on microbial treatment of waste; it has 1 screen, 2
Correspondence: Chebor Joel, Department of Biological Sciences, University of Eldoret, P.O. Box 1125, Eldoret, Kenya.

E-mail: jochebor@gmail.com

Key words: Slow sand filtration, effluent, irrigation, wastewater, seasons.

Contributions: CJ, conception and design of the research article; LAM, analyzing and interpreting the data; EKK, revising critically the article for important intellectual content. All the authors approved the study.

Conflict of interest: the authors declare no potential conflict of interest.

Funding: none.

Acknowledgements: the authors sincerely appreciated Eldoret Water and Sanitation Company (ELDOWAS) for according the permission to undertake this research at their facility and also for the assistance with their equipments, consumables and technical staff which made us to achieve the objectives of this study.

Received for publication: 31 July 2017.

Revision received: 26 September 2017.

Accepted for publication: 1 December 2017.

This work is licensed under a Creative Commons Attribution NonCommercial 4.0 License (CC BY-NC 4.0).

CC Copyright J. Chebor et al., 2018

Licensee PAGEPress, Italy

Microbiology Research 2018; 9:7269

doi:10.4081/mr.2018.7269

primary ponds, 1 secondary pond, 1 sedimentation pond, 1 tertiary pond and 2 trickling filters. The study was carried out during dry and wet seasons where parameters were tested in three replicates. Sewage treatment at Boundary Treatment Plant takes 13 days from the inlet to outlet. It takes four days at the primary pond, approximately two minutes at the filter, few minutes at the sedimentation tank, four days at secondary pond, and five days at the tertiary pond. In the present study, samples for analysis were collected as follows: inlet sample on day one, primary pond sample after four days, filter sample same day as primary pond sample and final effluent after nine days. Five litres of the final effluent was taken to the laboratory and passed through the three sand filters. The collected samples from the treatment plant were analyzed for BOD, chemical oxygen demand (COD), total coliforms (TC), $\mathrm{pH}$, total dissolved solids (TDS) and total suspended solids (TSS) and then compared with both nation- 
al and international standards for treated wastewater to be utilized for crop irrigation. After comparing, the quantity of these parameters in which the treatment plant failed to treat to the standards for irrigation, one and half litres of the final effluent were passed through each of the assembled slow sand filters of grain sizes, $0.1 \mathrm{~mm}, 0.05 \mathrm{~mm}$ and a combination of the two sand sizes on a 26 feet plastic PVC pipe. The filtrate obtained from this filters were collected and further analyzed and compared with the same standards for irrigation.

Biological oxygen demand and TSS were compared with United States of America (Washington) standards, COD with standards of Jordan, while TC, $\mathrm{pH}$ and TDS were compared with the Kenyan national environmental management authority (NEMA) standards for treated wastewater to be used for irrigation. The standards for irrigation for the various parameters were obtained from various different countries that uses treated wastewater for irrigation because Kenya NEMA did not provide all the standards for all the parameters for the treated wastewater to be used for irrigation because irrigation in Kenya with wastewater whether treated or not is not allowed by the law however, poor urban residence practice it illegally.

\section{Total coliform analysis}

Final effluent and filtrate samples collected were serially diluted then pour plate technique as described by Ramesh ${ }^{12}$ on Eosin Methylene Blue was used and incubated at $37^{\circ} \mathrm{C}$ for 24 hours. Nucleated colonies with or without metallic sheen and pink in colour were counted with the aid of Gallenhamp colony counter. The populations of the viable colonies were obtained by the formula; number of counted colonies $\times$ dilution reciprocal. ${ }^{13}$

\section{Physicochemical analyses \\ Biological oxygen demand}

BOD was determined by the procedure described in BOD track manual (19951998). Nitrification inhibitor powder was dispensed into the empty sterile BOD bottle. Collected samples of 0.32-1.1 litres were homogenised in a blender for two minutes. The $\mathrm{pH}$ of the sample was adjusted to a range of 6.5 and 7.5 with Sulphuric acid or Sodium hydroxide then $355 \mathrm{~mL}$ of the sample was measured into the BOD. A 3.8 $\mathrm{cm}$ magnetic stir bar was placed in each sample bottle then stopcock grease was applied to the seal lip of each bottle and to the cap of each seal cap. One gram Lithium hydroxide powder pillow was added to each seal cap. The bottles were incubated for five days in a BOD incubator.

\section{Chemical oxygen demand}

COD was determined as described in COD manual (2002) where $100 \mathrm{~mL}$ of the final effluent and filtrate samples were first homogenized in a blender. Two millilitres of the homogenised samples were pipetted into low range reagents. Two millilitres of deionised water was added to the reagents to produce a blank, then the vials were inverted gently several times and placed in a COD reactor which had already been heated to a temperature of $150^{\circ} \mathrm{C}$ and left to heat for two hours. After this duration the vials were removed to cool to room temperature and finally a programmed Spectrophotometer machine was used to read the COD results.

\section{Total suspended solids}

The TSS was obtained by the procedure described by Eaton. ${ }^{14}$ A glass filter was dried by placing it in an oven with a temperature of $103^{\circ} \mathrm{C}$ for 60 minutes, removed and then put in a dessicator to cool for $60 \mathrm{~min}$ utes and weighed. A $100 \mathrm{~mL}$ of the homogenised sample was filtered through the glass filter. The weight of the sample was obtained by using the formula:

Total Suspended Solids $(\mathrm{mg}) / \mathrm{L}=(\mathrm{A}-\mathrm{B})$ $\times 1000 \div$ Sample volume

Where $\mathrm{A}=$ weight of filter plus dried residue in $\mathrm{mg}$ and $\mathrm{B}=$ weight of filter in $\mathrm{mg}$.

\section{Total dissolved solids}

The filtrate obtained from the testing for Total Suspended Solids described above was utilized for testing for Total Dissolved Solids by transferring them to a weighed evaporating dish and then evaporated to dryness on a steam bath. This was followed by drying for one hour at $180^{\circ} \mathrm{C}$ then cooling for one hour in a dessicator. ${ }^{14}$

Weight of TDS was obtained using the formulae by Eaton. ${ }^{14}$

Total Dissolved Solids $(\mathrm{mg}) / \mathrm{L}=(\mathrm{A}-\mathrm{B})$ $\times 1000 \div$ Sample volume

Where $\mathrm{A}=$ weight of dried residue plus dish in $\mathrm{mg}$ and $\mathrm{B}=$ weight of dish in $\mathrm{mg}$

\section{pH}

The $\mathrm{pH}$ of the final effluent and filtrate was obtained by using $\mathrm{pH}$ meter.

\section{Statistical analysis}

The data obtained from the final effluent and the filtrate during the two seasons were analysed by one sample $t$-test procedure using SAS 9.2 software in comparison with the various standards for sufficiently treated wastewater to be used in irrigation. Significance level of $95 \%$ was used.

\section{Results}

\section{Comparison of the final effluent with recommended standards for irrigation during dry season}

The quantity of Biological oxygen demand, chemical oxygen demand, total suspended solids, total dissolved solids and $\mathrm{pH}$ in the final effluent from Boundary Sewage Treatment Plant were compared with the standards for treated wastewater to be used in crop irrigation during dry season as demonstrated in Table 1.

The quantity of $\mathrm{pH}$ and TDS in the final effluent from Boundary Wastewater Treatment Plant were not significantly $(\mathrm{P}>0.05)$ higher than the recommended standards of between 6.5 and 8.5 for $\mathrm{pH}$ and of $\leq 1200$ for TDS for the treated wastewater to be used in irrigation during dry season. However, the quantity of BOD, COD, TC and TSS in the final effluent were significantly $(\mathrm{P}<0.05)$ above the standards recommended for the wastewater to be used for irrigation of $\leq 30 \mathrm{mg} / \mathrm{L}, \quad \leq 100 \mathrm{mg} / \mathrm{L}$, $\leq 1000 \mathrm{mg} / \mathrm{L}, \leq 30 \mathrm{mg} / \mathrm{L}$ for BOD, COD, TC and TSS respectively during dry season hence rendering the treated wastewater unsuitable for irrigation during dry season.

Table 1. Comparison of final effluent with the recommended standards for treated wastewater to be used for irrigation during dry season.

\begin{tabular}{lccc} 
Parameters & Mean \pm SE & Recommended standards & P-value \\
BOD $(\mathrm{mg} / \mathrm{L})$ & $82.67 \pm 4.33$ & $\leq 30(\mathrm{mg} / \mathrm{L})$ (Washington) & 0.0034 \\
COD $(\mathrm{mg} / \mathrm{L})$ & $169.0 \pm 0$ & $\leq 100(\mathrm{mg} / \mathrm{L})$ (Jordan) & $<.0001$ \\
\hline $\mathrm{pH}$ & $8.05 \pm 0.03$ & $\geq 6.5(\mathrm{NEMA})$ & 0.9998 \\
$\mathrm{pH}$ & $8.05 \pm 0.03$ & $\leq 8.5(\mathrm{NEMA})$ & 0.9982 \\
$\mathrm{TC}(\mathrm{cfu} / 100 \mathrm{~mL})$ & $4500.0 \pm 0$ & $\leq 1000(\mathrm{cfu} / 100 \mathrm{~mL})(\mathrm{NEMA})$ & $<.0001$ \\
TDS $(\mathrm{mg} / \mathrm{L})$ & $722.7 \pm 9.21$ & $\leq 1200(\mathrm{mg} / \mathrm{L})(\mathrm{NEMA})$ & 0.9998 \\
\hline TSS $(\mathrm{mg} / \mathrm{L})$ & $90.00 \pm 0$ & $\leq 30(\mathrm{mg} / \mathrm{L})($ Washington $)$ & $<.0001$ \\
\hline
\end{tabular}

BOD, Biological Oxygen Demand; TDS, Total Dissolved Solids; COD, Chemical Oxygen Demand; TSS, Total Suspended Solids; TC, Total coliforms; NEMA, Kenya National Environmental Management authority. 


\section{Comparison of the final effluent with the recommended standards for irrigation during wet season}

The parameters that were determined at the final effluent at the Boundary Sewage Treatment Plant were compared with the standards for wastewater to be used in irrigation during wet season as shown in Table 2. $\mathrm{pH}, \mathrm{BOD}, \mathrm{COD}$ and TDS in the final effluent from Boundary Sewage Treatment Plant during wet season were significantly not $(\mathrm{P}>0.05)$ higher than the standards recommended for irrigation. $\mathrm{pH}$ in the final effluent during wet season was within the range of between 6.5 to 8.5 for treated wastewater to be used for irrigation, Biological Oxygen Demand, chemical oxygen demand and total dissolved solids were below the recommended standards for wastewater to be used for irrigation of $\leq 30$ $(\mathrm{mg} / \mathrm{L}), \leq 100(\mathrm{mg} / \mathrm{L})$ and $\leq 1200(\mathrm{mg} / \mathrm{L})$ respectively. However, TSS and TC were significantly $(\mathrm{P}<0.05)$ higher than the recommended standards for irrigation rendering the wastewater unsuitable for irrigation. Total suspended solids and total coliforms were above the standards for irrigation of $\leq 30 \quad(\mathrm{mg} / \mathrm{L})$ and $\leq 1000(\mathrm{cfu} / 100 \mathrm{~mL})$ respectively (Table 2 ).

\section{Comparison of the filtrate with the standards recommended for irriga- tion during dry season}

Biological oxygen demand, chemical oxygen demand, total suspended solids and total coliforms that were not treated by boundary wastewater treatment plant during dry season to the recommended standards for the treated wastewater to be used in irrigation (Table 3) were subjected to slow sand filtration of three sand filters; $0.1 \mathrm{~mm}$, $0.05 \mathrm{~mm}$ and the mixture of the two $(0.1 \mathrm{~mm}$ and $0.05 \mathrm{~mm}$ ) in an effort to improve the final effluent for irrigation.

Biological oxygen demand and total suspended solids were significantly $(<0.05)$ higher than the compared standard for the filtrate from $0.1 \mathrm{~mm}$ sand filter to be used in irrigation. Biological oxygen demand in the filtrate recorded a mean of $33.33 \mathrm{mg} / \mathrm{L}$ against recommended standard for irrigation of $\leq 30 \mathrm{mg} / \mathrm{L}$ while TSS in the $0.1 \mathrm{~mm}$ filtrate was $81.67 \mathrm{mg} / \mathrm{L}$ against $\leq 30 \mathrm{mg} / \mathrm{L}$ recommended for the filtrate to be used for irrigation. However, COD and TC obtained in the $0.1 \mathrm{~mm}$ sand filter filtrate were not significantly $(>0.05)$ above the recommended standards for the filtrate to be used in irrigation.

The quantity of BOD, COD, TSS and TC obtained in the filtrate from $0.05 \mathrm{~mm}$ slow sand filter were significantly not $(>0.05)$ higher than the compared standards of treated wastewater to be utilised in irrigation. BOD of $27.67 \mathrm{mg} / \mathrm{L}$ was lower than 30 $\mathrm{mg} / \mathrm{L}, \mathrm{COD}$ of $62.33 \mathrm{mg} / \mathrm{L}$ was lower than recommended standards of less than 100 $\mathrm{mg} / \mathrm{L}$, TSS of $23.33 \mathrm{mg} / \mathrm{L}$ was lower than compared standard of $30 \mathrm{mg} / \mathrm{L}$ and TC of $600 \mathrm{cfu} / 100 \mathrm{~mL}$ was lower than the compared standard of $100 \mathrm{cfu} / 100 \mathrm{~mL}$.

All the parameters; BOD, COD, TSS and TC tested in the filtrate from slow sand filter made of mixture of $0.1 \mathrm{~mm}$ and 0.05 $\mathrm{mm}$ sand sizes were significantly not $(<0.05)$ higher than the compared standards for treated wastewater to be used in irrigation. Biological oxygen demand of 28.33 $\mathrm{mg} / \mathrm{L}$ was lower than the recommended standard for irrigation of $30 \mathrm{mg} / \mathrm{L}, \mathrm{COD}$ in the filtrate of $70.00 \mathrm{mg} / \mathrm{L}$ was below the irrigation standard of $\leq 100 \mathrm{mg} / \mathrm{L}$, TSS of 26.33 in the filtrate was within the standard for the filtrate to be used in irrigation of $\leq 30$ $\mathrm{mg} / \mathrm{L}$ and $\mathrm{TC}$ of 813.3 . cfu/ $100 \mathrm{~mL}$ was within the standard of $\leq 100 \mathrm{cfu} / 100 \mathrm{~mL}$ for the filtrate to be used in irrigation.

\section{Comparison of the filtrate with the} recommended standards recom-

\section{mended for irrigation during wet} season

Total coliforms and TSS that were not treated by Boundary Sewage Treatment Plant during wet season to the recommended standards for irrigation (Table 2) were subjected to slow sand filtration for further treatment in an effort to improver them to be suitable for irrigation. Three types of slow sand filters made were employed, one was made of $0.1 \mathrm{~mm}$ sand size another was made of $0.05 \mathrm{~mm}$ and another was composed of mixture of $0.1 \mathrm{~mm}$ and $0.05 \mathrm{~mm}$ sand sizes. The findings were $\mathrm{s}$ shown in Table 4.

Total coliforms in the filtrate from 0.05 $\mathrm{mm}$ slow sand filter during wet season were significantly not $(>0.05)$ higher than the compared standards for the filtrate to be used for irrigation. The $706.7 \mathrm{cfu} / 100 \mathrm{~mL}$ of total coliforms in the filtrate were less than the compared amount of $\leq 1000 \mathrm{cfu} / 100 \mathrm{~mL}$. The amount of total suspended solids in the filtrate were significantly $(<0.05)$ higher than the compared standard for the filtrate to be used for irrigation.

Table 2. Comparison of the final effluent with the standards for treated wastewater to be used in irrigation during wet season.

\begin{tabular}{lccc} 
Parameters & Mean \pm SE & Recommended standards & P-value \\
BOD $(\mathrm{mg} / \mathrm{L})$ & $28.00 \pm 0$ & $\leq 30(\mathrm{mg} / \mathrm{L})$ (Washington) & 1.0000 \\
COD $(\mathrm{mg} / \mathrm{L})$ & $76.67 \pm 0.33$ & $\leq 100(\mathrm{mg} / \mathrm{L})($ Jordan $)$ & 0.9999 \\
\hline TC $(\mathrm{cfu} / 100 \mathrm{~mL})$ & $1600.0 \pm 0$ & $\leq 1000(\mathrm{cfu} / 100 \mathrm{~mL})(\mathrm{NEMA})$ & $<.0001$ \\
TDS $(\mathrm{mg} / \mathrm{L})$ & $357.3 \pm 3.67$ & $\leq 1200(\mathrm{mg} / \mathrm{L})(\mathrm{NEMA})$ & 1.0000 \\
TSS $(\mathrm{mg} / \mathrm{L})$ & $62.00 \pm 1.00$ & $\leq 30(\mathrm{mg} / \mathrm{L})(\mathrm{NEMA})$ & 0.0005 \\
$\mathrm{pH}$ & $8.03 \pm 0.03$ & $\geq 6.5(\mathrm{NEMA})$ & 0.9998 \\
\hline $\mathrm{pH}$ & $8.03 \pm 0.03$ & $\leq 8.5(\mathrm{NEMA})$ & 0.9975 \\
\hline
\end{tabular}

BOD, Biological Oxygen Demand; TDS, Total Dissolved Solids; COD, Chemical Oxygen Demand; TSS, Total Suspended Solids; TC, Total coliforms; NEMA, Kenya National Environmental Management authority.

Table 3. Comparison of $0.1 \mathrm{~mm}$ sand filter filtrate with the standards recommended for irrigation during dry season.

\begin{tabular}{lccc} 
Parameters & Mean \pm SE & Recommended standards & P-value \\
BOD $(\mathrm{mg} / \mathrm{L})$ & $33.33 \pm 0.33$ & $\leq 30$ & 0.0049 \\
COD $(\mathrm{mg} / \mathrm{L})$ & $74.33 \pm 5.17$ & $\leq 100$ & 0.9808 \\
\hline TSS $(\mathrm{mg} / \mathrm{L})$ & $81.67 \pm 0.67$ & $\leq 30$ & $<.0001$ \\
TC $(\mathrm{cfu} / 100 \mathrm{~mL})$ & $960.0 \pm 11.55$ & $\leq 1000$ & 0.9629
\end{tabular}

Table 4. Comparison of $\mathbf{0 . 0 5} \mathbf{~ m m}$ sand filter filtrate with the standards recommended for irrigation during dry season.

\begin{tabular}{lccc} 
Parameters & Mean \pm SE & Recommended standards & P-value \\
BOD $(\mathrm{mg} / \mathrm{L})$ & $27.67 \pm 0.67$ & $\leq 30$ & 0.9636 \\
COD $(\mathrm{mg} / \mathrm{L})$ & $62.33 \pm 1.45$ & $\leq 100$ & 0.9993 \\
\hline TSS $(\mathrm{mg} / \mathrm{L})$ & $23.33 \pm 3.33$ & $\leq 30$ & 0.9082 \\
TC $(\mathrm{cfu} / 100 \mathrm{~mL})$ & $600.0 \pm 0$ & $\leq 1000$ & 1.0000 \\
\hline
\end{tabular}


The two parameters TC and TSS obtained in the filtrate from $0.05 \mathrm{~mm}$ slow sand filter were significantly lower $(>0.05)$ than the recommended standards for the filtrate to be used for irrigation. The amount of TC in the filtrate was $400 \mathrm{cfu} / 100 \mathrm{~mL}$ and TSS was $15 \mathrm{mg} / \mathrm{L}$ compared with the standards for irrigation of $\leq 1000 \mathrm{cfu} / 100$ $\mathrm{mL}$ and $\leq 30 \mathrm{mg} / \mathrm{L}$ respectively.

Total coliforms and total suspended solid in the filtrate obtained from mixture $(0.05$ and $0.1 \mathrm{~mm})$ sand filter were significantly lower $(>0.05)$ than the recommended standards for the filtrate to be used for irrigation. The amount of TC in the filtrate was $440 \mathrm{cfu} / 100 \mathrm{~mL}$ and TSS was $26 \mathrm{mg} / \mathrm{L} \mathrm{com}$ pared with the standards for irrigation of $\leq 1000 \mathrm{cfu} / 100 \mathrm{~mL}$ and $\leq 30 \mathrm{mg} / \mathrm{L}$ respectively (Tables 5-8).

\section{Discussion}

Both the two wastewater treatment systems involved in this study; Boundary Sewage Treatment Plant and the slow sand filtration treated their respective influent to either up to the standards recommended for crop irrigation or reduced the amount of the parameter in the wastewater but failed to achieve the standard for irrigation.

Total dissolved solids and $\mathrm{pH}$ met the recommended standards for irrigation during both dry and wet seasons for the treated wastewater from Boundary Sewage Treatment Plant to be used for irrigation. This attainment could be attributed to the sufficient treatment of the wastewater at the various stages of primary pond, trickling filter, sedimentation, secondary and tertiary ponds at the treatment plant. Denitrification process could have contributed to the reduction of TDS to the acceptable level for irrigation. Nitrate passing through the process of denitrification was reduced to nitrous oxide and in turn nitrogen gas. Since nitrogen gas has low water solubility, it escapes into the atmosphere as gas bubbles. ${ }^{15}$ The reduction of the amount of TDS in the wastewater to the standard suitable for the treated wastewater to be used for irrigation also could be due to reduction of phosphate at the ponds through by accumulation of polyphosphate by microorganisms. ${ }^{16}$ The achievement of $\mathrm{pH}$ was also due to the various treatment processes at the various stages at the treatment plant. Anaerobic digestion occurring in the sludge at the bottom of the primary pond in BWTP results in converting organic load in the influent to methane and carbon dioxide and releasing some soluble organic acids into the water column. ${ }^{17}$ The position of oxypause similarly changes as does the $\mathrm{pH}$ since at peak algal activity carbonate and bicarbonate ions react to provide more carbon dioxide leaving an excess of hydroxyl ions increasing the $\mathrm{Ph}$ of the wastewater. ${ }^{15}$ The generation of hydrogen and hydroxyl ions during the process of wastewater treatment contributed to the attainment of the recommended standards for the wastewater to be suitable for irrigation purposes.

On contrary, TSS and TC in the wastewater were not treated to the recommended standards for irrigation during the two seasons by BWTP. The lagging of TSS could be due to its increase at the trickling filter compared to its preceding stage of primary pond rather than decreasing. The droppings of the birds swimming at the secondary and tertiary ponds at the treatment plant would have contributed to increase of TC, making the plant inefficient. ${ }^{18,19}$ observed that from the drinking water production stand point the presence of aquatic birds at the water reservoirs was associated with decreasing quality of water. The lack of any physical instrument that can remove the fine debris at the BWSTP might also have contributed to the treatment plant no to achieve the irrigation standards during the two seasons.
Biological Oxygen Demand and COD were not treated to the recommended standard for irrigation during dry season this could be due to lack of dilution of the wastewater by direct rainfall to the open treatment ponds at BSTP which took place during wet season on top of conventional wastewater treatment process. These findings concur with those of Kayima ${ }^{20}$ who attributed their relative higher values of BOD and COD in dry season than wet to dilution of the stream by rain. ${ }^{21}$ in his study on seasonal variation on grey water also concluded that the fewer amounts of COD in rainy season than winter and summer was a result of more amount of water used by more/less occupants in a house during September and due to less dilution occurred in greywater during January. Similarly in earlier studies by Mara ${ }^{22}$ they demonstrated that the design parameters such as BOD in oxidation ponds attain maximum values in the hot season and minimum values in the wet/cold season.

The slow sand filters except the one with $0.1 \mathrm{~mm}$ grain size improved the quality of the wastewater to the level that can be used for irrigation during both the dry and

Table 5. Comparison of mixture $(0.01 \mathrm{~mm}$ and $0.05 \mathrm{~mm})$ sand filter filtrate with the standards recommended for irrigation during dry season.

\begin{tabular}{lccc} 
Parameters & Mean \pm SE & Recommended standards & P-value \\
BOD $(\mathrm{mg} / \mathrm{L})$ & $28.33 \pm 0.33$ & $\leq 30$ & 0.9811 \\
COD $(\mathrm{mg} / \mathrm{L})$ & $70.00 \pm 0.58$ & $\leq 100$ & 0.9998 \\
\hline TSS $(\mathrm{mg} / \mathrm{L})$ & $26.33 \pm 0.33$ & $\leq 30$ & 0.9959 \\
TC $(\mathrm{mg} / \mathrm{L})$ & $813.3 \pm 3.33$ & $\leq 1000$ & 0.9998 \\
\hline
\end{tabular}

Table 6. Comparison of the $0.1 \mathrm{~mm}$ slow sand filtrate with the standards recommended for irrigation during wet season.

\begin{tabular}{lccc} 
Parameters & Mean \pm SE & Recommended standards & P-value \\
TC $(\mathrm{cfu} / 100(\mathrm{~mL})$ & $706.7 \pm 3.33$ & $\leq 1000$ & 0.9999 \\
$\mathrm{TSS}(\mathrm{mg} / \mathrm{L})$ & $55.00 \pm 0$ & $\leq 30$ & $<.0001$ \\
\hline
\end{tabular}

Table 7. Comparison of the $0.1 \mathrm{~mm}$ slow sand filtrate with the standards recommended for irrigation during wet season.

\begin{tabular}{lccc} 
Parameters & Mean \pm SE & Recommended standards & P-value \\
TC $(\mathrm{cfu} / 100 \mathrm{~mL})$ & $400.0 \pm 0$ & $\leq 1000$ & 1.0000 \\
TSS $(\mathrm{mg} / \mathrm{L})$ & $15.00 \pm 2.89$ & $\leq 30$ & 0.9825 \\
\hline
\end{tabular}

Table 8. Comparison of the mixture slow and filtrate with the standards recommended for irrigation during wet season.

\begin{tabular}{lccc} 
Parameters & Mean \pm SE & Recommended standards & P-value \\
TC $(\mathrm{cfu} / 100 \mathrm{~mL})$ & $440.0 \pm 0$ & $\leq 1000$ & 1.0000 \\
TSS $(\mathrm{mg} / \mathrm{L})$ & $26.00 \pm 0.58$ & $\leq 30$ & 0.9899 \\
\hline
\end{tabular}


wet seasons. The efficiency of the sand filters in improving the final effluent from the treatment plant across the two seasons could be attributed to the various treatment mechanisms in the sand filters. Several mechanisms for the removal of particles, microorganisms and organic matter exist in slow sand filters have been documented. As water percolates through the sand, organic material and microorganism are removed by both mechanical (absorption, diffusion, screening and sedimentation) and biological processes (predation, natural death and metabolic breakdown. ${ }^{23}$

However the lagging of slow sand filter $\mathrm{T}(0.1 \mathrm{~mm})$ to treat the wastewater to the recommended standards for irrigation could be its larger sand sizes compared to the other two sand sizes used in the study which could have allowed the final effluent from BSTP to just pass through without sufficient treatment. Earlier studies also established that filters with large sand grain sizes have higher filtration rates and thereby decreased retention of water in the biologically active regions of the filters that are necessary for filtration efficiency. ${ }^{24,25}$

\section{Conclusions}

Boundary Sewage Treatment Plant treated $\mathrm{pH}$ and TDS during dry season and BOD, COD, TDS and $\mathrm{pH}$ during wet season to the recommended standards for irrigation. However, it did not treat BOD, COD, TSS and total coliforms to the recommended standards during dry season and TSS and total coliforms during wet season. This treatment plant proved to be more efficient during wet season than during dry season. During wet season the plant achieved the recommended standards for irrigation for most of the parameters than during dry season.

The slow sand filters achieved the parameters that the treatment plant failed to achieve to be used for irrigation. Filter $\mathrm{T}$ of $0.1 \mathrm{~mm}$ failed to reduce BOD and TSS during dry season to the recommended standards for irrigation.

\section{References}

1. Al-Jasser AO. Saudi wastewater reuse standards for agricultural irrigation: Riyadh treatment plants effluent compliance. J King Saud University Engin
Sci 2011;31:1-8.

2. Scott CA, Faruqui NI, Raschid-Sally L. Wastewater use in irrigated agriculture: Confronting the livelihood and environmental realities. CABI 2004;25.

3. Keraita B, Jiménez B, Drechsel P. Extent and implications of agricultural reuse of untreated, partly treated and diluted wastewater in developing countries. CAB reviews: Perspect Agric Vet Sci Nutr Nat Res 2008;3:1-5.

4. World Health Organization. Guidelines for the safe use of wastewater, excreta and greywater. World Health Organization; 2006.

5. Van der Hoek, Hassan W, Ensink UM, et al. Urban wastewater: a valuable resource for agriculture. International Water Management Institute, Research Report 63, Colombo, Sri Lanka; 2002.

6. Morrison G, Fatoki OS, Persson L, Ekberg A. Assessment of the impact of point source pollution from the Keiskammahoek Sewage Treatment Plant on the Keiskamma River-pH, electrical conductivity, oxygendemanding substance (COD) and nutrients. Water Sa 2001;27:475-80.

7. United States Department of Defense (USDOD): Unified Facilities Criteria for domestic Wastewater Treatment System Augmenting Handbook. UFC 3240-02N; 2004.

8. Logsdon GS, Kohne R, Abel S, LaBonde S. Slow sand filtration for small water systems. J Environ Engin Sci 2002;1:339-48.

9. Rooklidge SJ, Burns ER, Bolte JP. Modeling antimicrobial contaminant removal in slow sand filtration, Water Res 2009;39:331-9.

10. Adin A. Slow granular filtration for water reuse. Water Sci Technol: Water Supply. 2003;3:123-30.

11. Weber-Shirk ML, Chan KL. The role of aluminum in slow sand filtration. Water Research 2006;41:1350-4.

12. Ramesh KJ. Environmental microbiology. Chania: MJP Publishers; 2004.

13. Madigan MT, Martinko JM, Dunlap PV, Clark D. Brock Biology of Microorganisms. 12th ed. San Francisco, CA: Pearson International; 2009.

14. Eaton AD, Clesceri LS, Greenberg AE. APHA. AWWA, WEF, Standard methods for the examination of water and wastewater. 19th edn, Washington, DC,
USA 1995.

15. Mackne C, Lake A, Casey P, Solomon C. Trickling filters achieving filtration factsheet published by national small flows clearing house. 1998.

16. Prescott LM, Harley JP, Klein DA. Microorganisms in aquatic environments. In: Prescott LM, ed. Microbiology, 5th ed. New York, NY: McGraw-Hill; 2002. pp 632-663.

17. IETC-UNEP. Environmentally sound technologies for wastewater and storm water management: International source book, UNEP international environmental technology centre (IETC). 2002.

18. Smith HV, Brown J, Coulson JC, et al. Occurrence of oocysts of Cryptosporidium sp. in Larus spp. gulls. Epidemiol Infection 1993;110:135-43.

19. Kirschner AK, Zechmeister TC, Kavka $\mathrm{GG}$, et al. Integral strategy for evaluation of fecal indicator performance in bird-influenced saline inland waters. Appl Environ Microbiol 2004;70:7396403.

20. Kayima J, Kyakula M, Komakech W, Echimu SP. A study of the degree of Pollution in Nakivubo Channel, Kampala, Uganda. J Appl Sci Environ Managm 2008;12.

21. Maltreyee MT. Seasonal Variation in greywater quality for real life system. Int J Res Engin Toxicol 2014:768-70.

22. Mara DD, Pearson HW. Artificial fresh water environments: waste stabilization ponds. Biotechnology 8. W. Schoernbon: 1998. pp 177-206.

23. Logsdon GS, Kohne R, Abel S, LaBonde S. Slow sand filtration for small water systems. J Environ Engin Sci 2002;1:339-48.

24. Goitom K. Performance of pilot scale slow sand filters using different local sands in Ethiopia. Tampere University of Technology, Institute of Water and Environmental Engineering; 1990.

25. Van Der Hook JP, Boorle PAC, Kors LJ, Te Welsche RAG. Slow sand filtration: Effects of grain size and filtration rate on operation and performance. In: Graham N, Collins R. Advances in slow sand and alternative biological filtrations. John Wiley and Sons Ltd, UK; 1996. 